\title{
Insights to Repository Performance Through Study of a Nuclear Test Site
}

D.K. Smith, A.B. Kersting, J.L Thompson, D.L. Finnegan

This article was submitted to $24^{\text {th }}$ Symposium on the Scientific Basis for Nuclear Waste Management, Sydney, Australia, August 27-31, 2000

January 14, 2000 


\section{DISCLAIMER}

This document was prepared as an account of work sponsored by an agency of the United States Government. Neither the United States Government nor the University of California nor any of their employees, makes any warranty, express or implied, or assumes any legal liability or responsibility for the accuracy, completeness, or usefulness of any information, apparatus, product, or process disclosed, or represents that its use would not infringe privately owned rights. Reference herein to any specific commercial product, process, or service by trade name, trademark, manufacturer, or otherwise, does not necessarily constitute or imply its endorsement, recommendation, or favoring by the United States Government or the University of California. The views and opinions of authors expressed herein do not necessarily state or reflect those of the United States Government or the University of California, and shall not be used for advertising or product endorsement purposes.

This is a preprint of a paper intended for publication in a journal or proceedings. Since changes may be made before publication, this preprint is made available with the understanding that it will not be cited or reproduced without the permission of the author.

This report has been reproduced directly from the best available copy.

Available electronically at http://www.doe.gov/bridge

Available for a processing fee to U.S. Department of Energy and its contractors in paper from

U.S. Department of Energy

Office of Scientific and Technical Information

$$
\text { P.O. Box } 62
$$

Oak Ridge, TN 37831-0062

Telephone: (865) 576-8401

Facsimile: (865) 576-5728

E-mail: reports@adonis.osti.gov

Available for the sale to the public from

U.S. Department of Commerce

National Technical Information Service

5285 Port Royal Road

Springfield, VA 22161

Telephone: (800) 553-6847

Facsimile: (703) 605-6900

E-mail: orders@ntis.fedworld.gov

Online ordering: http://www.ntis.gov/ordering.htm

OR

Lawrence Livermore National Laboratory

Technical Information Department's Digital Library

http://www.llnl.gov/tid/Library.html 


\title{
INSIGHTS TO REPOSITORY PERFORMANCE THROUGH STUDY OF A NUCLEAR TEST SITE
}

\author{
David K. Smith and Annie B. Kersting \\ Analytical and Nuclear Chemistry Division \\ Lawrence Livermore National Laboratory \\ Livermore, California 94550 USA \\ Joseph L. Thompson and David L. Finnegan \\ Chemical Sciences and Technology Division, \\ Los Alamos National Laboratory \\ Los Alamos, New Mexico 87545 USA
}

United States high-level nuclear waste from nuclear weapons production, naval propulsion programs, and the processing of commercial spent nuclear fuels is scheduled for immobilization in glass waste forms prior to permanent disposal in a mined geologic repository. Considerable attention has been directed to assessments of the subsequent long-term release of radionuclides from a repository under saturated and partially saturated conditions. Credible predictions of dose from a repository rely on insights to radionuclide sequestration in the glass, mechanisms of glass degradation, and radionuclide solubility and transport in the near-field.

Underground nuclear test sites offer an unprecedented opportunity to evaluate processes relevant to repository performance in the absence of engineered barriers. Radionuclide migration programs at the Nevada Test Site represent a twenty-five year investment in the systematic investigation of the diverse radiologic source term from weapons testing and the evolution of the hydrologic source term which includes radionuclides dissolved in or otherwise available for transport by groundwater.

The geology, hydrology, and geochemistry of the Nevada Test Site which includes the proposed Yucca Mountain repository provides an ideal natural laboratory to assess long-term radionuclide transport in the near and far-field. The Yucca Mountain repository shares with adjacent testing areas the following features: correlative volcanic geology, an identical tectonic and structural setting, similar recharge and climate, and a thick fractured unsaturated zone. In many cases nuclear tests are more than thirty years old and the hydrologic source term has geochemically evolved toward equilibrium during this time.

Adequate containment of underground nuclear explosions at the Nevada Test Site necessitated conducting tests underground at depths of burial between 600 and $1200 \mathrm{~m}$ below ground surface. The majority were fired above the water table; however higher yield tests which required deeper containment were fielded in the saturated zone. During an underground nuclear explosion nearly 1000 metric tons of glass is produced per kiloton of nuclear yield. More than $90 \%$ of $\mathrm{Pu}, \mathrm{Np}$, and $\mathrm{U}$ and long-lived fission products including $\mathrm{Eu}, \mathrm{Ce}$, and $\mathrm{Zr}$ are incorporated in the glass. The glass dissolves through hydration and hydrolysis reactions. Intrinsic dissolution rates are approximately $1 \mathrm{E}-5 \mathrm{grams} / \mathrm{m}^{2} /$ day at 
$25^{\circ} \mathrm{C}$ and near-neutral $\mathrm{pH}$. Elevated temperatures in the vicinity of the explosion may persist for many years post event, speeding glass dissolution and causing radionuclides to ascend by convection to shallow aquifers where they may be transported laterally in the near-field. Ultimately, soluble anionic, oxyanionic, and gaseous radionuclides including ${ }^{3} \mathrm{H},{ }^{14} \mathrm{C},{ }^{36} \mathrm{Cl},{ }^{85} \mathrm{Kr},{ }^{99} \mathrm{Tc},{ }^{125} \mathrm{Sb}$, and ${ }^{129} \mathrm{I}$ move conservatively with groundwater. Cationic radionuclides including ${ }^{22} \mathrm{Na},{ }^{60} \mathrm{Co}$, ${ }^{90} \mathrm{Sr},{ }^{137} \mathrm{Cs}$ are largely attenuated by ion exchange and adsorption to authigenic clays and zeolite minerals in the near-field. Relatively insoluble radionuclides including Pu and Eu may be mobilized by sorption onto clay and zeolite colloids and transported in low concentrations (1E-14M) at ambient groundwater velocities $(\sim 50 \mathrm{~m} /$ year $)$ in areas characterized by high hydraulic gradients and extensive fracturing.

The fate and transport of actinide and long-lived fission product source terms away from a repository and underground nuclear test site are comparable. One scenario identified in assessments of repository performance is the percolation of infiltrating seepage water which breaches a waste canister and carries radioactive material of colloid size downwards towards the saturated zone. The test site analog uses surface water recharging through a rubble chimney to leach radionuclides from the melt glass in the explosion cavity. A study of migration in the saturated zone would provide insight to sorption and precipitation of reactive radionuclides and dilution and dispersion of non-sorbing species. An optimum test site selected for a repository analog would provide the advantages of being accessible, geologically and hydrologically well characterized, with a known radionuclide source term. Specific considerations in developing a test site analog to the Yucca Mountain repository would include selection of:

- a nuclear test where the depth of (device) burial is shallow $(800 \mathrm{~m})$ to minimize drilling costs and recovery of post-shot debris.

- a site where a successful post-shot drill-back has occurred to provide information on the cavity size and the identity and distribution of radionuclides present in the region adjacent to the working point.

- a geologic environment similar to that found in the repository.

- a location where the source and quantity of recharge can be quantified and the geology is well characterized.

- a test where sufficient time has elapsed for radionuclides to be released from and transported away from the cavity.

- a setting entirely within the unsaturated zone to insure that transport would only involve two-phase flow downward to the saturated zone.

The Nevada Test Site provides a unique opportunity to observe radionuclide and unsaturated zone interactions to assess the performance of natural barriers in attenuating radionuclide transport. Analog studies may validate predictions of radionuclide transport from the proposed Yucca Mountain repository.

This work was performed under the auspices of the U.S. Department of Energy by the University of California, Lawrence Livermore National Laboratory under Contract No. W-7405-Eng-48. 